\title{
Towards a Capabilities Taxonomy for Prognostics and Health Management
}

\author{
Jeff Bird, Nancy Madge, and Karl Reichard \\ Education and Professional Development Committee of the PHM Society \\ jbird@magma.ca \\ nmadge@magma.ca \\ kmr5@psu.edu
}

\begin{abstract}
This communication proposes the development by the PHM Society of a classification or taxonomy for the skills needed for the prognostics and health management (PHM) field. This taxonomy is a set of descriptors for each skill for a chosen range of competency levels: entry, working and mastery. This communication defines a structure and process to ensure application to real needs by employers, practitioners and training developers. Preliminary results of the development of Analytics, Test and Experiment Design and Cost Benefit Studies sub-domains within the PHM field are reported based on workshops at the PHM 2012 and 2013 Annual Conferences. Steps for a way forward are proposed and mechanisms for interested parties to participate are suggested. The PHM Society's Education and Professional Development Committee would lead these efforts.
\end{abstract}

\section{BACKGROUND}

Prognostics and Health Management (PHM) is a diverse, multi-disciplinary domain with rapidly evolving capability needs. Initial education and training from many discipline entry points must be complemented by specialized and professional development over a PHM career.

The community's stakeholders in academia, industry and government require a stream of qualified practitioners with lifelong professional development.

The community has identified that benchmarks are needed for career planners, employers and training developers. For example, stakeholders are interested in facilitating transitions between competency levels.

Aligned with this scenario, the PHM Society has general objectives to:

Bird et al. This is an open-access article distributed under the terms of the Creative Commons Attribution 3.0 United States License, which permits unrestricted use, distribution, and reproduction in any medium, provided the original author and source are credited.
- Promote the development, growth, and recognition of prognostics and health management (PHM) as an engineering discipline;

- Support PHM education by developing standard teaching curricula in the field; and

- Establish, develop, or adopt standards, methods, and metrics in PHM.

To accomplish these objectives the board of the Society has approved activities in this direction overseen by a committee on Education and Professional Development (EPD).

\section{Proposal}

The proposed taxonomy or classification delineates PHM educational into skill and capability areas and by competency levels within each skill and/or capability. The taxonomy is captured in matrices with entries in rows and columns. Examples are listed below:

Skill/capability areas: PHM domains, e.g. signal processing, statistics, control systems, [as rows],

Competency levels: Entry, Working or Mastery for each [as columns].

Employers, practitioners, and training and professional course developers will use the taxonomy for hiring, training identification and selection, and training/course development.

Employers: A job description could be readily prepared to include a capabilities list from various areas with desired competency levels. Evaluation schemes could reference competency levels to be demonstrated or developed. Professional development transitions could be defined and matched to courses or in-house assignments.

Practitioners: To plan education and professional development progressions and understand skills and capabilities required. 
Training and professional course developers: To identify niche course product areas. Specifically, descriptors would be commonly understood for likely pre-requisites available and new competencies to be acquired.

\section{COMPETENCY DEFINITIONS}

Competency definitions are required for this use of such a taxonomy. Pedagogical references provide a basis for this selection of a working set (Carnegie Mellon University, 2013) based on fundamentals developed by Bloom (1956).

The progression of complexity is typical within the hierarchies used for taxonomies. The National Research Council Canada (NRC) has developed a soft skill hierarchy (NRC, 2013). As an example, the creative thinking skill is defined to respond to challenges with innovative solutions, products or services by questioning conventional means, using intuition, experimentation and fresh perspectives. Five levels of competency with descriptors are provided for this skill:

Level 1: Understands how to solve problems

- Uses common sense and knowledge to identify underlying issues and to solve problems.

- Uses appropriate problem-solving techniques.

Level 2: Identifies existing solutions

- Reviews existing options, concepts and approaches, and identifies one(s) that will work in the situation at hand.

- Stands back from a problem and observes patterns and interrelationships in data to see where problems or discrepancies arise.

- Recognizes and assesses several likely causes or ways of interpreting available information.

- Recognizes when a new approach is needed to solve a problem.

- Solves complex problems through application of existing theories or explanations.

Level 3: Modifies existing solutions

- Questions traditional solutions and uses unconventional methods to find solutions.

- Thinks about problems from a new perspective.

- Solves problems by applying ideas from other disciplines or fields of research.

Level 4: Creates new solutions/concepts

- Thinks several steps ahead in deciding on best course of action (anticipates likely outcomes).

- Creates, assesses and applies new concepts, theories, approaches and/or solutions.

- Solves complex or inter-related problems through developing new theories, explanations or applications.

Level 5: Impacts a field of science/technology
- Develops new theories and applications with revolutionizing or wide-ranging impacts.

As an alternative to this soft skill hierarchy, a technical skill can also be categorized by breadth of application (Reichard, 2012), in a three level approach:

1. Engineering and technical contribution at the subsystem level is required.

2. The conversion of concepts to subsystems and systems, major system design and/or technical leader in multiple projects.

3. A developer of engineering concepts, major system design, and/or technical leader in multiple programs. A principal contributor in systems design, systems engineering, concept development, and project reports.

For the PHM taxonomy considered here, we have decided to use three levels that incorporate important aspects of these two above approaches:

1. Entry Level: Understands, selects, interprets and applies basic concepts and known methods. May work at the sub-system level.

2. Working Level: Analyses and solves complex problems by combining or extending existing methods. Likely integrates and validates at the system level.

3. Mastery Level: Evaluates, innovates, synthesizes and validates new methods through unique, often multidisciplinary insights.

Application of skills may include analysis, design, build/implement and test for equipment, hardware and software.

\section{PHM SKILLS AND CAPABILITIES}

Compiling a list of possible skills for PHM practitioners is challenging because the field is multi-disciplinary. A generic IVHM taxonomy has been proposed by Jennions (2011). He identifies key high-level IVHM system components: service offerings, business, systems design, architecture, analytics, technologies, applications and support.

This work aims to extend existing taxonomies to meet the multiple stakeholder needs (Section 2) with a comprehensive list of skills. Firstly, we propose to subdivide skills and capabilities as follows:

1. Domain: major category of a technical skill or competency

2. Sub-domain: constituent sub category that could be associated with a stream of graduate courses

3. Specialty: subject that could constitute a specific course

While it is acknowledged that there are overlaps between the domains, a working list of key PHM domains and subdomains (with some sample specialties) is proposed: 
1. System physical modeling
a. Fluid mechanics- aerodynamics, hydraulics/hydrodynamics
b. Electrical/Electronics
c. Mechanical
d. Structural
e. Thermodynamics
f. Data driven- bond graphs
g. Hybrid approaches

2. Data Modeling
a. Parametric
b. Non-parametric
c. Hybrid

3. Analytics

a. Data pre-processing

b. Feature extraction

c. Feature selection

d. Classification- methods, metrics

e. Regression- methods, metrics

f. Optimization- methods, metrics

g. Model Fusion

h. Anomaly Detection

i. Fault Isolation- observability, coverage

j. Prognostics- specialized methods, metrics (e.g. latency)

k. Data Fusion by data types

1. Special Issues with time series data

m. Special Issues with nominal data types

n. Reasoners- meta-classifiers, Bayesian, fuzzy logic

Note: Diagnostics is considered to comprise e to $\mathrm{i}$ and $\mathrm{n}$

4. Test and Experimental (Design and conduct)

a. Data acquisition- steady state, targeted, transient, dynamic

b. Inspection/evaluation- NDI/E

c. Uncertainty analysis

d. Sensor

e. Data reduction

f. Data transmission

g. Fault implantation

5. Software Systems

a. Architecture- standards

b. Real time system

c. User interfaces

d. Software system integration (up to enterprise integration)

e. Data compression

6. Hardware Systems

a. Off board- standards

b. On board- standards

c. Sensors- design, specification, integration

7. Life Cycle Analysis

a. Root cause analysis

b. Fault Tree Analysis

c. Functional Hazard Analysis d. Fault accommodation

e. Trade studies

f. Reliability

g. Availability

h. Maintainability

i. FMECA- FM, E, C

j. Logistics

8. Verification and Validation

a. Methods

b. Maturation

9. Human Factors

a. Needs analysis- standards

b. Usability - standards

10. Systems Engineering
a. Usage Monitoring

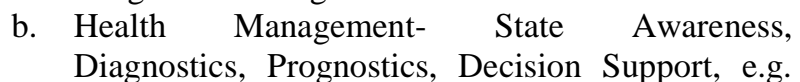 Contingency -based Management
c. Autonomous systems

11. Cost Benefit Analysis
a. Needs analysis
b. Risk Analysis
c. Metrics, uncertainty/confidence and evaluation
d. Business case
e. Support Service/Performance Based Logistics approaches

12. Certification
a. Standards
b. Safety Status Analysis
c. Risk management
d. Post certification management

13. Standards

\section{SAMPle CAPABILITIES-COMPETENCY MAPPING}

Here we take a practitioner skills/capability viewpoint as opposed to the IVHM system components view. This approach follows a general model: application of existing tools at the entry level, adaptation at the working level and customization or new methods at the mastery level.

A sample taxonomy entry is provided in Table 1 for the Analytics domain and Diagnostics sub-domain, with three competency level descriptors. Additional rows of descriptors could be added to Table 1 to accommodate the complexity of the analysis, and hands-on or other appropriate skills 


\begin{tabular}{|c|c|c|c|}
\hline Specialty & $\begin{array}{l}\text { Entry } \\
\text { Level } \\
\text { descriptors }\end{array}$ & $\begin{array}{l}\text { Working } \\
\text { Level } \\
\text { descriptors }\end{array}$ & $\begin{array}{l}\text { Mastery } \\
\text { Level } \\
\text { descriptors }\end{array}$ \\
\hline Methods & $\begin{array}{l}\text { Apply } \\
\text { existing } \\
\text { single and } \\
\text { multi- } \\
\text { disciplinary } \\
\text { methods } \\
\ldots\end{array}$ & $\begin{array}{l}\text { Assess } \\
\text { shortcomings } \\
\text { in existing } \\
\text { methods- } \\
\text { adapt/hybridize } \\
\text { methods to suit } \\
\ldots\end{array}$ & $\begin{array}{l}\text { Develop new } \\
\text { methods } \\
\text { from novel } \\
\text { physics or } \\
\text { mathematical } \\
\text { insights } \\
\ldots\end{array}$ \\
\hline Metrics & $\begin{array}{l}\text { Apply } \\
\text { appropriate } \\
\text { existing } \\
\text { metrics } \\
\ldots\end{array}$ & $\begin{array}{l}\text { Adapt metrics } \\
\text { to complex } \\
\text { system } \\
\text { evaluation } \\
\ldots\end{array}$ & $\begin{array}{l}\text { Devise and } \\
\text { approve } \\
\text { system level } \\
\text { metrics } \\
\ldots\end{array}$ \\
\hline
\end{tabular}

Table 1. Sample Taxonomy Entry

\section{DEVELOPMENT OF TAXONOMY}

The PHM Society Education and Professional Development Committee sponsored a workshop at the PHM 2012 Annual Conference to develop the concept described above. Three significant domains were selected, each had a broad based group examine the sub-domain list and also to draft competency descriptors. While these resulting products for Analytics, Test and Experiment Design and Cost Benefit Analysis are neither complete nor final, it was felt that the developing a 'straw man' version would be helpful to the Society to assess the feasibility of producing a complete taxonomy. Details follow for these workshop products.

\subsection{Domain 1- Analytics}

The working group at the PHM 2012 conference agreed to accept the sub-domains in section 4 above. However, they considered the prognostics sub-domain separate and were not able to address it in the time available. They proposed working versions of the competency descriptions for most of the sub-domains in that list and added some specific specialties within some sub-domains. For a number of the specialties/analysis tools they chose the same generic descriptors. Annex 1 provides the results. In general, they proposed application of existing tools at the entry level, adaptation at the working level and customization or new methods at the mastery level.

\subsection{Domain 2- Test and Experiment Design}

The working group at the conference added additional subdomains: integration, fault injection/insertion, data validation, data reduction and data management. They chose not to add specialties in the limited time available.
The descriptors addressed a number of diverse skills and capabilities across the hardware/software/sensor scope of this domain. Details are provided in Annex 2.

\subsection{Domain 3- Cost Benefit Analysis}

The group who discussed the Cost Benefit Analysis domain proposed adding sub-domains for asset management, maintenance and the effect of prognostics management, and business versus customer perspective. It was also suggested that metrics, uncertainty/confidence and evaluation might be considered as specialties within the risk analysis subdomain. Details are provided in Annex 3.

\section{CONCLUSIONS AND WAY FORWARD}

The need for a broadly applicable PHM taxonomy has received a preliminary validation through a limited workshop process at the PHM 2012 Annual Conference. The three classes of users were confirmed. The general form and a working set of definitions have been developed and reviewed. Draft taxonomies for three PHM domains have been proposed for further development through either workshops or specialists. The appropriate number and level of detail for the specialties is yet to be determined.

The PHM Society Education and Professional Development (EPD) Committee is coordinating actions to:

1. Prepare and circulate a Working Model of a PHM Capabilities Taxonomy- this communication document.

2. Conduct Conference Workshops covering evolving issues and the taxonomy approach- planned for PHM 2013.

3. Develop the inputs for this taxonomy from subject matter experts.

4. Compile sources for entry-level skills.

5. Compile courses available for transitions across competency levels from existing materials and programs in various organizations.

6. Identify gaps in current post-secondary and graduate continuing education materials and opportunities.

Linkages with the SAE HM-1 committee will ensure that this work is complementary to other efforts. In the longer term, the PHM Society expects to work with appropriate organizations to develop needed materials and opportunities. To that end, the PHM Society is establishing a comprehensive set of technical co-sponsorships with major organizations.

Interested parties are invited and encouraged to contribute by contacting one of the authors or participating in the online forum at www.phmsociety.org/forum/577. 


\section{ACKNOWLEDGEMENT}

The EPD Committee acknowledges the contributions of PHM conference attendees who have participated in panels and workshops from 2009-2012. Particular guidance and support is acknowledged from Dr. Kai Goebel, Dr. Neil Eklund, Prof. Ian Jennions, and Prof. George Vachtsevanos.

\section{REFERENCES}

Carnegie Mellon University. Whys and Hows of Assessment. Accessed Oct 26, 2013 at www.cmu.edu/teaching/assessment/howto/assessprogra $\mathrm{m} /$ masterymodel.html

Bloom, B. (1956). Taxonomy of Educational Objectives, Handbook I: The Cognitive Domain. New York: David McKay, 1956. Also see a summary, accessed Oct 26, 2013 at http://oaks.nvg.org/taxonomy-bloom.html

National Research Council Canada, Soft Skill Competencies Accessed archive Oct 26, 2013 at http://archive.nrc-cnrc.gc.ca/eng/careers/behaviouralcompetencies/research-creative-thinking.html

Reichard, K. (2012). Personal communication.

Jennions I.K. (2011). Integrated Vehicle Health Management: Perspectives on an Emerging Field, SAE International Product Code R-405

\section{BIOGRAPHIES}

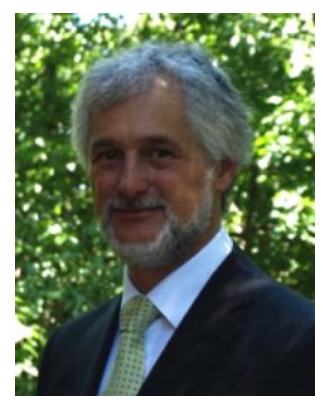

Jeff Bird is currently a consultant with TECnos Consulting Services, Ottawa, Canada. His present avocations include advancing the art, science and business of prognostics and health management in diverse fields. Specifically, he leads PHM Society board initiatives in Education and Professional Development as well as Standards. He recently completed one career spanning 30 years as a Research Officer at the Gas Turbine Laboratory of the National Research Council Canada. His published research there included gas turbine dynamics and performance, health monitoring and management, adverse environments, and uncertainty. Previously he worked as an Operational Research officer in the Department of National Defence where he enjoyed contributing to airlift and search and rescue planning. He studied at the University of Toronto (Engineering Science- Aerospace) and at Carleton University (Mechanical, Aerospace and Systems)



Nancy Madge is a partner at TECnos Consulting Services. She specializes in curriculum development for adult learning and training in industrial and professional settings. Over some 28 years, she has developed user needs definitions, course designs and materials for participants and instructors across diverse applications such as telephony, calculus, tax law, computer systems and process operation. Her Bachelor's qualifications are in Music Education at the University of Western Ontario complemented by Master's work in curriculum design at Brock University. She completed integrated arts and education coursework towards a doctorate at the University of Toronto's Ontario Institute for Studies in Education.

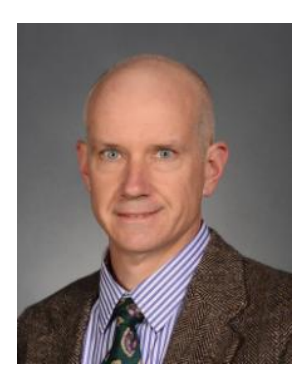

Dr. Karl Reichard is a Research Associate at the Applied Research Laboratory at The Pennsylvania State University and Deputy Department Head of the Advanced Sensors and Controls Department in the Multisensor Processing Division. $\mathrm{He}$ has more than 15 years of experience in the development of advanced sensors, measurement systems, and signal processing algorithms. An Assistant Professor of Acoustics at Penn State and Head of the Condition-Based Maintenance Department at the University's Applied Research Laboratory, Dr. Reichard leads advanced research and development efforts in embedded systems, electrooptics, intelligent acoustic and vibration sensors, and signal processing and classification algorithms for active noise and vibration control, manufacturing machinery monitoring, and surveillance systems. Prior to joining Penn State ARL in 1991, he was employed by the U.S. Army Aberdeen Proving Grounds and Virginia Polytechnic Institute and State University, his alma mater. Dr. Reichard has published more than 25 papers in refereed journals, conference publications, and technical reports. Dr. Reichard serves as Associate Editor of the International Journal on Prognostics and Health Management. 
Annex 1: Draft Taxonomy for Analytics Domain

\begin{tabular}{|c|c|c|c|c|}
\hline Sub-domain & Specialty & $\begin{array}{ll}\text { Entry } & \text { Level } \\
\text { descriptors } & \end{array}$ & $\begin{array}{ll}\text { Working } & \text { Level } \\
\text { descriptors } & \end{array}$ & $\begin{array}{ll}\text { Mastery } & \text { Level } \\
\text { descriptors } & \end{array}$ \\
\hline \multirow[t]{2}{*}{ Diagnostics } & Methods & $\begin{array}{l}\text { Apply existing single } \\
\text { and multi-disciplinary } \\
\text { methods } \\
\text { Other }\end{array}$ & $\begin{array}{l}\text { Assess shortcomings in } \\
\text { existing methods- } \\
\text { adapt/hybridize } \\
\text { methods to suit } \\
\text { Other }\end{array}$ & $\begin{array}{l}\text { Develop new methods } \\
\text { from novel physics or } \\
\text { mathematical insights }\end{array}$ \\
\hline & Metrics & $\begin{array}{l}\text { Apply appropriate } \\
\text { existing metrics }\end{array}$ & 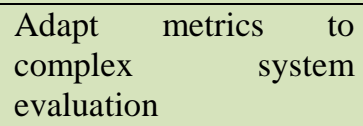 & $\begin{array}{lr}\text { Devise and bring into } \\
\text { acceptance } & \text { system } \\
\text { level metrics } & \end{array}$ \\
\hline \multirow[t]{4}{*}{$\begin{array}{l}\text { Data Pre- } \\
\text { Processing }\end{array}$} & $\begin{array}{l}\text { De-noising } \\
\text { Outlier } \\
\text { Detection }\end{array}$ & $\begin{array}{l}\text { Ability to implement } \\
\text { and apply algorithms. } \\
\text { Ability to understand } \\
\text { algorithms }\end{array}$ & $\begin{array}{l}\text { Ability to decide which } \\
\text { algorithms to apply, } \\
\text { choose parameters for } \\
\text { analysis, modify } \\
\text { existing algorithms }\end{array}$ & $\begin{array}{l}\text { Develop new } \\
\text { techniques and } \\
\text { approaches based on } \\
\text { mathematical insight }\end{array}$ \\
\hline & Transformation & & & \\
\hline & $\begin{array}{l}\text { Database } \\
\text { Design }\end{array}$ & $\begin{array}{l}\text { Understand and use } \\
\text { database }\end{array}$ & $\begin{array}{l}\text { Ability to choose } \\
\text { appropriate database } \\
\text { design from existing } \\
\text { designs and match tools } \\
\text { to PHM requirements }\end{array}$ & $\begin{array}{l}\text { Customization of } \\
\text { database, database } \\
\text { design, optimization }\end{array}$ \\
\hline & $\begin{array}{l}\text { Special } \text { Issues } \\
\text { with nominal } \\
\text { data types }\end{array}$ & & & $\begin{array}{l}\text { Ability to recognize } \\
\text { and apply appropriate } \\
\text { processing techniques } \\
\text { to accommodate } \\
\text { differences in data } \\
\text { types }\end{array}$ \\
\hline \multicolumn{5}{|l|}{$\begin{array}{l}\text { Feature } \\
\text { Extraction }\end{array}$} \\
\hline \multirow[t]{3}{*}{$\begin{array}{l}\text { Feature } \\
\text { Selection }\end{array}$} & $\begin{array}{l}\text { Physics } \\
\text { Engineering } \\
\text { Approaches }\end{array}$ & $\begin{array}{l}\text { Works with SME to } \\
\text { identify techniques and } \\
\text { applies/implements }\end{array}$ & $\begin{array}{l}\text { Understands how to } \\
\text { decompose } \\
\text { problem/system and } \\
\text { identifies appropriate } \\
\text { SME }\end{array}$ & $\begin{array}{l}\text { Develop engineering } \\
\text { or physical models } \\
\text { and new techniques }\end{array}$ \\
\hline & $\begin{array}{l}\text { Statistical } \\
\text { Approaches }\end{array}$ & $\begin{array}{l}\text { Ability to implement } \\
\text { and apply algorithms. } \\
\text { Ability to understand } \\
\text { algorithms }\end{array}$ & $\begin{array}{l}\text { Ability to decide which } \\
\text { algorithms to apply, } \\
\text { choose parameters for } \\
\text { analysis, modify } \\
\text { existing algorithms }\end{array}$ & $\begin{array}{l}\text { Develop new } \\
\text { techniques and } \\
\text { approaches based on } \\
\text { mathematical insight. } \\
\text { Ability to work cross } \\
\text { domain with Machine } \\
\text { Learning or } \\
\text { Engineering/physical } \\
\text { approaches }\end{array}$ \\
\hline & $\begin{array}{l}\text { Machine } \\
\text { Learning }\end{array}$ & $\begin{array}{l}\text { Ability to implement } \\
\text { and apply algorithms. }\end{array}$ & $\begin{array}{l}\text { Ability to decide which } \\
\text { algorithms to apply, } \\
\text { choose parameters for }\end{array}$ &  \\
\hline
\end{tabular}




\begin{tabular}{|c|c|c|c|c|}
\hline Sub-domain & Specialty & $\begin{array}{ll}\text { Entry } & \text { Level } \\
\text { descriptors }\end{array}$ & $\begin{array}{ll}\text { Working } & \text { Level } \\
\text { descriptors }\end{array}$ & $\begin{array}{ll}\begin{array}{l}\text { Mastery } \\
\text { descriptors }\end{array} & \text { Level }\end{array}$ \\
\hline & & $\begin{array}{l}\text { Ability to understand } \\
\text { algorithms }\end{array}$ & $\begin{array}{l}\text { analysis, modify } \\
\text { existing algorithms }\end{array}$ & $\begin{array}{l}\text { mathematical insight. } \\
\text { Ability to work cross } \\
\text { domain with statistical } \\
\text { approaches or } \\
\text { Engineering/physical } \\
\text { approaches }\end{array}$ \\
\hline \multirow[t]{4}{*}{ Classification } & $\begin{array}{l}\text { Cluster Analysis } \\
\text { / Unsupervised } \\
\text { Learning }\end{array}$ & $\begin{array}{l}\text { Ability to implement } \\
\text { and apply algorithms. } \\
\text { Ability to understand } \\
\text { algorithms }\end{array}$ & $\begin{array}{l}\text { Ability to decide which } \\
\text { algorithms to apply, } \\
\text { choose parameters for } \\
\text { analysis, } \\
\text { existing modify } \\
\begin{array}{l}\text { Knows algorithms. } \\
\text { techniques }\end{array}\end{array}$ & $\begin{array}{l}\text { Develop new } \\
\text { techniques and } \\
\text { approaches based on } \\
\text { mathematical insight. } \\
\text { Increased breadth of } \\
\text { knowledge }\end{array}$ \\
\hline & $\begin{array}{l}\text { Supervised } \\
\text { Learning }\end{array}$ & $\begin{array}{l}\text { Ability to implement } \\
\text { and apply algorithms. } \\
\text { Ability to understand } \\
\text { algorithms }\end{array}$ & $\begin{array}{l}\text { Ability to decide which } \\
\text { algorithms to apply, } \\
\text { choose parameters for } \\
\text { analysis, modify } \\
\text { existing algorithms. } \\
\begin{array}{l}\text { Knows } \\
\text { techniques }\end{array}\end{array}$ & $\begin{array}{l}\text { Develop new } \\
\text { techniques and } \\
\text { approaches based on } \\
\text { mathematical insight. } \\
\text { Increased breadth of } \\
\text { knowledge }\end{array}$ \\
\hline & $\begin{array}{l}\text { Statistical } \\
\text { Approaches }\end{array}$ & $\begin{array}{l}\text { Ability to implement } \\
\text { and apply algorithms. } \\
\text { Ability to understand } \\
\text { algorithms }\end{array}$ & $\begin{array}{l}\text { Ability to decide which } \\
\text { algorithms to apply, } \\
\text { choose parameters for } \\
\text { analysis, modify } \\
\text { existing algorithms. } \\
\begin{array}{l}\text { Knows } \\
\text { techniques }\end{array}\end{array}$ & $\begin{array}{l}\text { Develop new } \\
\text { techniques and } \\
\text { approaches based on } \\
\text { mathematical insight. } \\
\text { Increased breadth of } \\
\text { knowledge }\end{array}$ \\
\hline & Metrics & $\begin{array}{l}\text { Apply appropriate } \\
\text { existing metrics }\end{array}$ & $\begin{array}{lr}\text { Adapt } & \text { metrics } \\
\text { complex } & \text { to } \\
\text { evaluation } & \text { system }\end{array}$ & $\begin{array}{lr}\text { Devise and bring into } \\
\text { acceptance } & \text { system } \\
\text { level metrics }\end{array}$ \\
\hline \multirow[t]{2}{*}{ Regression } & $\begin{array}{l}\text { Statistical } \\
\text { Techniques }\end{array}$ & $\begin{array}{l}\text { Ability to implement } \\
\text { and apply algorithms. } \\
\text { Ability to understand } \\
\text { algorithms }\end{array}$ & $\begin{array}{l}\text { Ability to decide which } \\
\text { algorithms to apply, } \\
\text { choose parameters for } \\
\text { analysis, modify } \\
\text { existing algorithms. } \\
\text { Knows multiple } \\
\text { techniques. Ability to } \\
\text { understand and apply } \\
\text { hybrid techniques }\end{array}$ & $\begin{array}{l}\text { Develop new } \\
\text { techniques and } \\
\text { approaches based on } \\
\text { mathematical insight. } \\
\text { Increased breadth of } \\
\text { knowledge. }\end{array}$ \\
\hline & $\begin{array}{l}\text { Machine } \\
\text { Learning }\end{array}$ & $\begin{array}{l}\text { Ability to implement } \\
\text { and apply algorithms. } \\
\text { Ability to understand } \\
\text { algorithms }\end{array}$ & $\begin{array}{l}\text { Ability to decide which } \\
\text { algorithms to apply, } \\
\text { choose parameters for } \\
\text { analysis, modify } \\
\text { existing algorithms. } \\
\text { Knows multiple } \\
\text { techniques. Ability to } \\
\text { understand and apply } \\
\text { hybrid techniques }\end{array}$ & $\begin{array}{l}\text { Develop new } \\
\text { techniques and } \\
\text { approaches based on } \\
\text { mathematical insight. } \\
\text { Increased breadth of } \\
\text { knowledge }\end{array}$ \\
\hline Optimization & Gradient-based & TBD & TBD & TBD \\
\hline
\end{tabular}




\begin{tabular}{|c|c|c|c|c|}
\hline Sub-domain & Specialty & $\begin{array}{ll}\text { Entry } & \text { Level } \\
\text { descriptors } & \end{array}$ & $\begin{array}{l}\text { Working } \quad \text { Level } \\
\text { descriptors }\end{array}$ & $\begin{array}{ll}\text { Mastery } & \text { Level } \\
\text { descriptors }\end{array}$ \\
\hline & Evolutionary & TBD & TBD & TBD \\
\hline & $\begin{array}{l}\text { Operations } \\
\text { Research }\end{array}$ & TBD & TBD & TBD \\
\hline Model Fusion & & $\begin{array}{l}\text { Applies existing } \\
\text { algorithms. } \\
\text { Understanding of basic } \\
\text { voting techniques }\end{array}$ & $\begin{array}{l}\text { Ability to decide on } \\
\text { which algorithms to } \\
\text { employ, understanding } \\
\text { of machine learning and } \\
\text { statistical techniques }\end{array}$ & $\begin{array}{l}\text { Development of new } \\
\text { techniques }\end{array}$ \\
\hline $\begin{array}{l}\text { Fault } \\
\text { Detection and } \\
\text { Isolation } \\
\text { (includes } \\
\text { anomaly } \\
\text { detection) }\end{array}$ & & $\begin{array}{l}\text { Ability to implement } \\
\text { and apply algorithms. } \\
\text { Ability to understand } \\
\text { algorithms }\end{array}$ & $\begin{array}{l}\text { Ability to decide which } \\
\text { algorithms to apply, } \\
\text { choose parameters for } \\
\text { analysis, } \\
\text { existing modify } \\
\text { Knows algorithms. } \\
\text { techniques }\end{array}$ & $\begin{array}{l}\text { Develop new } \\
\text { techniques and } \\
\text { approaches based on } \\
\text { mathematical insight. } \\
\text { Increased breadth of } \\
\text { knowledge }\end{array}$ \\
\hline \multirow[t]{3}{*}{ Data Fusion } & Data Level & TBD & & \\
\hline & Feature Level & TBD & & \\
\hline & Decision Level & TBD & & \\
\hline $\begin{array}{l}\text { Special Issues- } \\
\text { Time Series } \\
\text { Data }\end{array}$ & & TBD & & \\
\hline \multirow[t]{3}{*}{ Reasoners } & Bayesian & $\begin{array}{l}\text { Ability to implement } \\
\text { and apply algorithms. } \\
\text { Ability to understand } \\
\text { algorithms }\end{array}$ & $\begin{array}{l}\text { Ability to decide which } \\
\text { algorithms to apply, } \\
\text { choose parameters for } \\
\text { analysis, modify } \\
\text { existing algorithms. } \\
\text { Knows multiple } \\
\text { techniques. Ability to } \\
\text { understand and apply } \\
\text { hybrid techniques }\end{array}$ & $\begin{array}{l}\text { Develop new } \\
\text { techniques and } \\
\text { approaches based on } \\
\text { mathematical insight. } \\
\text { Increased breadth of } \\
\text { knowledge }\end{array}$ \\
\hline & Expert Systems & $\begin{array}{l}\text { Ability to implement } \\
\text { and apply algorithms. } \\
\text { Ability to understand } \\
\text { algorithms }\end{array}$ & $\begin{array}{l}\text { Ability to decide which } \\
\text { algorithms to apply, } \\
\text { choose parameters for } \\
\text { analysis, modify } \\
\text { existing algorithms. } \\
\text { Knows multiple } \\
\text { techniques. Ability to } \\
\text { understand and apply } \\
\text { hybrid techniques }\end{array}$ & $\begin{array}{l}\text { Develop new } \\
\text { techniques and } \\
\text { approaches based on } \\
\text { mathematical insight. } \\
\text { Increased breadth of } \\
\text { knowledge }\end{array}$ \\
\hline & Fuzzy Logic & $\begin{array}{l}\text { Ability to implement } \\
\text { and apply algorithms } \\
\text { Ability to understand } \\
\text { algorithms }\end{array}$ & $\begin{array}{l}\text { Ability to decide which } \\
\text { algorithms to apply, } \\
\text { choose parameters for } \\
\text { analysis, } \\
\text { existing modify } \\
\text { Knows algorithms. } \\
\text { techniques. Ability to } \\
\text { understand and apply }\end{array}$ & $\begin{array}{l}\text { Develop new } \\
\text { techniques and } \\
\text { approaches based on } \\
\text { mathematical insight. } \\
\text { Increased breadth of } \\
\text { knowledge }\end{array}$ \\
\hline
\end{tabular}




\begin{tabular}{|c|c|c|c|c|}
\hline Sub-domain & Specialty & $\begin{array}{ll}\text { Entry } & \text { Level } \\
\text { descriptors } & \end{array}$ & $\begin{array}{ll}\begin{array}{l}\text { Working } \\
\text { descriptors }\end{array} & \text { Level }\end{array}$ & $\begin{array}{ll}\begin{array}{l}\text { Mastery } \\
\text { descriptors }\end{array} & \text { Level }\end{array}$ \\
\hline & & & hybrid techniques & \\
\hline & Meta-Classifiers & $\begin{array}{l}\text { Ability to implement } \\
\text { and apply algorithms. } \\
\text { Ability to understand } \\
\text { algorithms }\end{array}$ & $\begin{array}{l}\text { Ability to decide which } \\
\text { algorithms to apply, } \\
\text { choose parameters for } \\
\text { analysis, modify } \\
\text { existing algorithms. } \\
\text { Knows multiple } \\
\text { techniques. Ability to } \\
\text { understand and apply } \\
\text { hybrid techniques }\end{array}$ & $\begin{array}{l}\text { Develop new } \\
\text { techniques and } \\
\text { approaches based on } \\
\text { mathematical insight. } \\
\text { Increased breadth of } \\
\text { knowledge }\end{array}$ \\
\hline Fault Isolation & & $\begin{array}{l}\text { Ability to implement } \\
\text { and apply algorithms. } \\
\text { Ability to understand } \\
\text { algorithms }\end{array}$ & $\begin{array}{l}\text { Ability to decide which } \\
\text { algorithms to apply, } \\
\text { choose parameters for } \\
\text { analysis, modify } \\
\text { existing algorithms. } \\
\text { Knows multiple } \\
\text { techniques. Ability to } \\
\text { understand and apply } \\
\text { hybrid techniques }\end{array}$ & $\begin{array}{l}\text { Develop new } \\
\text { techniques and } \\
\text { approaches based on } \\
\text { mathematical insight. } \\
\text { Increased breadth of } \\
\text { knowledge }\end{array}$ \\
\hline \multirow[t]{3}{*}{ Prognostics } & $\begin{array}{l}\text { Statistical } \\
\text { Techniques }\end{array}$ & TBD & & \\
\hline & $\begin{array}{l}\text { Machine } \\
\text { Learning }\end{array}$ & TBD & & \\
\hline & Physics- Based & TBD & & \\
\hline
\end{tabular}


Annex 2: Draft Taxonomy for Test and Experiment Design Domain

\begin{tabular}{|c|c|c|c|}
\hline Sub-domain & Entry Level descriptors & Working Level descriptors & Mastery Level descriptors \\
\hline $\begin{array}{l}\text { Design of } \\
\text { Experiment } \\
\text { (DOE) }\end{array}$ & Apply fully specified DOE & $\begin{array}{l}\text { Develop an experimental } \\
\text { design: replicates, environment, } \\
\text { initial conditions }\end{array}$ & $\begin{array}{l}\text { Modify } \quad \text { DOE } \\
\text { process/constraints/metrics }\end{array}$ \\
\hline $\begin{array}{l}\text { Data } \\
\text { Acquisition }\end{array}$ & $\begin{array}{l}\text { Program Lab view or } \\
\text { equivalent software } \\
\text { Set up and assemble } \\
\text { physical devices } \\
\begin{array}{l}\text { Assign sensors to } \\
\text { appropriate hardware }\end{array}\end{array}$ & $\begin{array}{l}\text { Select hardware and software } \\
\text { Define appropriate shielding } \\
\text { and signal methods, alignment } \\
\text { and calibration } \\
\text { Synchronize signals from } \\
\text { multiple sensors } \\
\text { Define appropriate telemetry or } \\
\text { remote methods }\end{array}$ & $\begin{array}{l}\text { Design and apply adaptive, } \\
\text { multidiscipline, multi } \\
\text { bandwidth methods }\end{array}$ \\
\hline $\begin{array}{l}\text { Inspection/ } \\
\text { Evaluation }\end{array}$ & $\begin{array}{l}\text { Apply known techniques at } \\
\text { sub system level, non- } \\
\text { destructive processes }\end{array}$ & $\begin{array}{l}\text { Select appropriate technique(s) } \\
\text { for a given component } \\
\text { Identify failure mode } \\
\text { characteristics } \\
\text { Interpret results }\end{array}$ & $\begin{array}{l}\text { Develop novel techniques } \\
\text { that combine multi-physics } \\
\text { methods }\end{array}$ \\
\hline $\begin{array}{l}\text { Measurement } \\
\text { Uncertainty } \\
\text { Analysis }\end{array}$ & $\begin{array}{lr}\text { Estimate } & \text { elemental } \\
\text { contributions } & \text { for } \\
\text { conventional } & \\
\text { measurements } & \\
\end{array}$ & $\begin{array}{l}\text { Develop propagated estimates } \\
\text { for parameters made up of many } \\
\text { elements } \\
\text { Develop calibration hierarchies } \\
\text { Develop elemental estimation } \\
\text { methods for complex } \\
\text { measurements }\end{array}$ & $\begin{array}{l}\text { Devise new estimation and } \\
\text { validation experiments } \\
\text { Develop novel estimation } \\
\text { methods for } \\
\text { systems }\end{array}$ \\
\hline Sensors & $\begin{array}{l}\text { Install sensors for basic } \\
\text { measurements } \\
\text { Interpret output signals }\end{array}$ & $\begin{array}{l}\text { Select sensors to meet detailed } \\
\text { requirements that are developed } \\
\text { at a system level: resolution, } \\
\text { bandwidth and repeatability }\end{array}$ & $\begin{array}{l}\text { Design a new sensor from } \\
\text { physic principles } \\
\text { Interpret complex } \\
\text { interactions of sensors with } \\
\text { environment }\end{array}$ \\
\hline Integration & 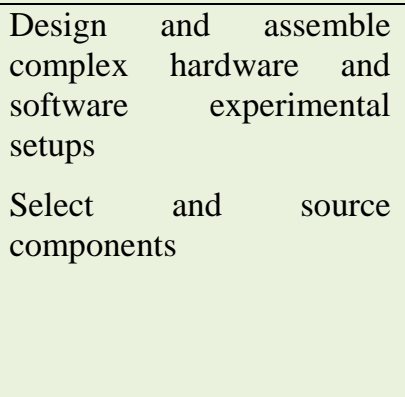 & $\begin{array}{l}\text { Define and prioritize essential } \\
\text { integration metrics and } \\
\text { functions to achieve high level } \\
\text { objectives: } \\
\text { mechanical, safety anysical, and, } \\
\text { reliability } \\
\begin{array}{l}\text { Design to meet cost effective } \\
\text { criteria and appropriate } \\
\text { complexity }\end{array}\end{array}$ & $\begin{array}{l}\text { Optimize design for complex } \\
\text { and conflicting constraints } \\
\text { Develop scalability methods }\end{array}$ \\
\hline $\begin{array}{l}\text { Fault injection/ } \\
\text { Insertion }\end{array}$ & $\begin{array}{l}\text { Conduct fully specified } \\
\text { fault injection tests } \\
\text { Validate test results against } \\
\text { baseline or reference data }\end{array}$ & $\begin{array}{l}\text { Apply existing fault modes in } \\
\text { destructive and non-destructive } \\
\text { ways } \\
\text { Develop controlled simulations } \\
\text { with system modifications: }\end{array}$ & $\begin{array}{l}\text { Design fault initiation and } \\
\text { propagation methods } \\
\text { Design and validate } \\
\text { accelerated/aging test } \\
\text { methods }\end{array}$ \\
\hline
\end{tabular}




\begin{tabular}{|c|c|c|c|}
\hline Sub-domain & Entry Level descriptors & Working Level descriptors & Mastery Level descriptors \\
\hline & & $\begin{array}{l}\text { simple biases and ramps } \\
\text { Define limiting assumptions } \\
\text { Apply relevant noise } \\
\text { simulations } \\
\text { Define and apply installation } \\
\text { and environment effects } \\
\text { Interpret usage information to } \\
\text { incorporate realistic test cases }\end{array}$ & 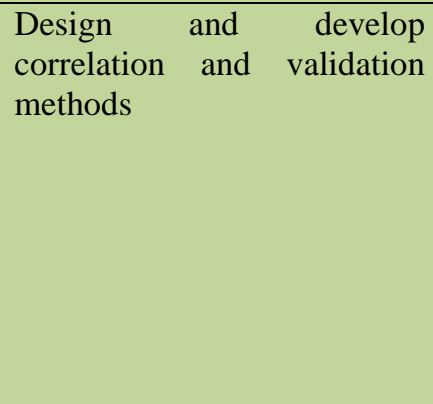 \\
\hline Data Validation & $\begin{array}{lcc}\text { Conduct functional } & \text { and } \\
\text { reality checks } & \text { for } \\
\text { conventional } & \\
\text { measurements } & \end{array}$ & $\begin{array}{l}\text { Design and conduct functional } \\
\text { and reality checks for transient } \\
\text { and dynamic data involving } \\
\text { complex sensor suites } \\
\text { Identify sources of error or } \\
\text { ambiguity in data }\end{array}$ & $\begin{array}{lr}\text { Design validation schemes } \\
\text { for } & \text { multidisciplinary } \\
\text { processes } & \end{array}$ \\
\hline Data Reduction & TBD & & \\
\hline $\begin{array}{l}\text { Data } \\
\text { Management }\end{array}$ & $\begin{array}{l}\text { Manage multiple data sets } \\
\text { ensuring providence and } \\
\text { database compilation }\end{array}$ & $\begin{array}{l}\text { Develop buffer and transmission } \\
\text { designs } \\
\begin{array}{l}\text { Define storage providence and } \\
\text { database implementation } \\
\text { methods }\end{array}\end{array}$ & \\
\hline
\end{tabular}


Annex 3: Draft Taxonomy for Cost Benefit Analysis

\begin{tabular}{|c|c|c|c|}
\hline Sub-domain & Entry Level descriptors & Working Level descriptors & $\begin{array}{ll}\text { Mastery } & \text { Level } \\
\text { descriptors } & \end{array}$ \\
\hline Needs Analysis & $\begin{array}{l}\text { Review requirements } \\
\text { and stakeholders } \\
\text { How to satisfy requirements }\end{array}$ & $\begin{array}{l}\text { Refining requirements } \\
\text { Review and refine stakeholders }\end{array}$ & $\begin{array}{l}\text { Defining requirements } \\
\text { Define new stakeholders }\end{array}$ \\
\hline Risk Analysis & $\begin{array}{l}\text { Identify known solutions } \\
\text { likelihood of success and } \\
\text { consequence } \\
\begin{array}{l}\text { Current } \\
\text { capabilities }\end{array}\end{array}$ & $\begin{array}{l}\text { Assess technology readiness level } \\
\text { Identify risks and consequences }\end{array}$ & $\begin{array}{l}\text { Analyze risk of novel } \\
\text { approaches }\end{array}$ \\
\hline $\begin{array}{l}\text { Metrics, } \\
\text { Uncertainty/ } \\
\text { Confidence and } \\
\text { Evaluation } \\
\text { (part of risk } \\
\text { analysis?) }\end{array}$ & $\begin{array}{l}\text { Capture data to facilitate } \\
\text { evaluation }\end{array}$ & $\begin{array}{l}\text { Evaluating performance against } \\
\text { metrics }\end{array}$ & $\begin{array}{lr}\begin{array}{l}\text { Setting metrics } \\
\text { conjunction }\end{array} & \text { in } \\
\text { stakeholders } & \text { with }\end{array}$ \\
\hline Business Case & $\begin{array}{l}\text { Given a business case } \\
\text { template, enter applicable } \\
\text { data }\end{array}$ & $\begin{array}{l}\text { Research existing business cases, } \\
\text { find applicable model } \\
\text { Apply and analyse impacts }\end{array}$ & $\begin{array}{l}\text { Create a business case } \\
\text { model to use in a new } \\
\text { novel scenario } \\
\begin{array}{l}\text { Design simulations to } \\
\text { demonstrate/prove case }\end{array}\end{array}$ \\
\hline $\begin{array}{l}\text { Support } \\
\text { Service/ } \\
\text { Performance } \\
\text { Based Logistics } \\
\text { approaches }\end{array}$ & TBD & & \\
\hline $\begin{array}{ll}\text { Return } & \text { On } \\
\text { Investment } & \end{array}$ & $\begin{array}{l}\text { Plug in data to existing } \\
\text { formulas }\end{array}$ & $\begin{array}{l}\text { Identify required changes to } \\
\text { business models } \\
\text { Define "what if" scenarios }\end{array}$ & $\begin{array}{l}\text { Creating new business } \\
\text { models }\end{array}$ \\
\hline $\begin{array}{l}\text { Asset } \\
\text { Management }\end{array}$ & TBD & & \\
\hline $\begin{array}{l}\text { Maintenance } \\
\text { and the Effect } \\
\text { of Prognostics } \\
\text { Management }\end{array}$ & TBD & & \\
\hline $\begin{array}{l}\text { Business versus } \\
\text { Customer } \\
\text { Perspective }\end{array}$ & TBD & & \\
\hline
\end{tabular}

